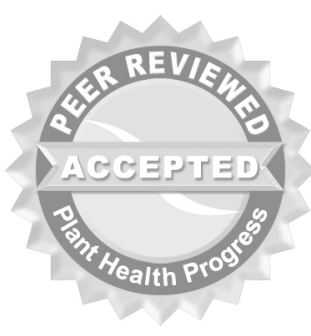

(c) 2007 Plant Management Network.

Accepted for publication 5 September 2006. Published 19 J uly 2007.

\title{
Improving our Understanding of Helicoverpa zea Migration in the Midwest: Assessment of Source Populations
}

\author{
Michael A. Sandstrom and David Changnon, Department of \\ Geography, Northern Illinois University, DeKalb 60115; and \\ Brian R. Flood, Del Monte Foods, Inc., 600 N. 15th Street, Rochelle, \\ IL 61068 \\ Corresponding author: Michael Sandstrom.wxtrw44@yahoo.com
}

Sandstrom, M. A., Changnon, D., and Flood, B. R. 2007. Improving our understanding of Helicoverpa zea migration in the Midwest: Assessment of source populations. Online. Plant Health Progress doi: 10.1094/PHP-2007-0719-08-RV.

\begin{abstract}
Corn earworm (Helicoverpa zea) (CEW) generally are not able to overwinter annually in the Upper Midwest, thus they must migrate northward to affect the primary vegetable-growing locations in this area. Migration of CEW is highly dependent on the weather. Provided a source region in the southern United States, migration of CEW from south to north appeared to occur when a highpressure system was located in the eastern United States and a low-pressure system and attendant frontal boundary was observed to the east of the Rocky Mountains and/or northern plains states. Southerly wind flow located west of the high and east of the low forms an "insect pump." Convection cells allowed CEW to lift and advance from their source region northward in the low-level insect pump. When CEW encountered an area of downward motion during their northward flight, such as a frontal boundary or a light precipitation area, they had a tendency to "drop out" of the sky into fields below, an area referred to as the "Drop Zone." Favorable weather patterns for CEW migration and subsequent infestation of fields in north-central Illinois were confirmed by high CEW trap counts at Rochelle over the last four decades.

\section{I ntroduction}

The midwestern United States is one of Earth's greatest crop-growing regions, providing a multitude of commodities to all corners of the globe. While field corn and soybeans are the most important, a myriad of other crops are also grown and constitute an important part of the economy. In the Midwest, sweet corn is another important crop. In 2002, 43\% of all harvested sweet corn acres in the United States were located in the Midwest, with almost $80 \%$ of these acres located specifically in Minnesota and Wisconsin (6).

Sweet corn, like many other crops, is susceptible to damage and yield loss from various diseases and pests, including the corn earworm (Helicoverpa zea) (CEW). CEW are responsible for a high percentage of yield reduction in sweet corn and are considered to be one of the costliest pests in the United States, resulting in the loss of millions of dollars annually (1). CEW, however, are not always present in many regions of the Midwest due to lethal periods of freezing temperatures during the winter (Fig. 1), and thus must migrate northward from warmer regions in the southern United States, especially south of Interstate 40 (2). The first generation of CEW usually appear in the southern reaches of the Midwest between April and J une, with areas roughly north of Interstate 80 not seeing CEW until between late J une and August (Fig. 2) (8).
\end{abstract}




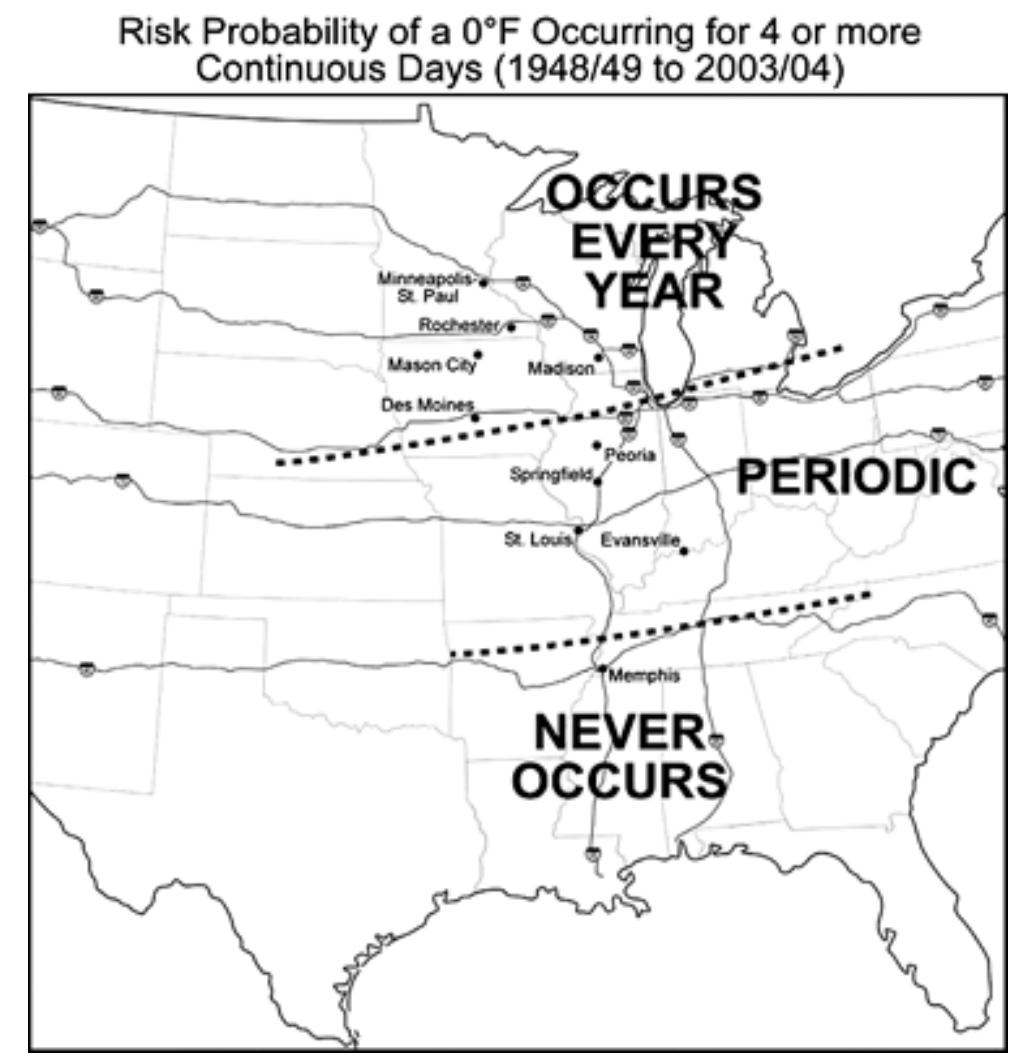

Fig. 1. Due to periods of prolonged cold temperatures during the winter, CEW generally are unable to overwinter north of Interstate 80, and always survive the winter south of Interstate 40, with occasional survival in between (Midwestern Regional Climate Center/NIU Cartography Laboratory).

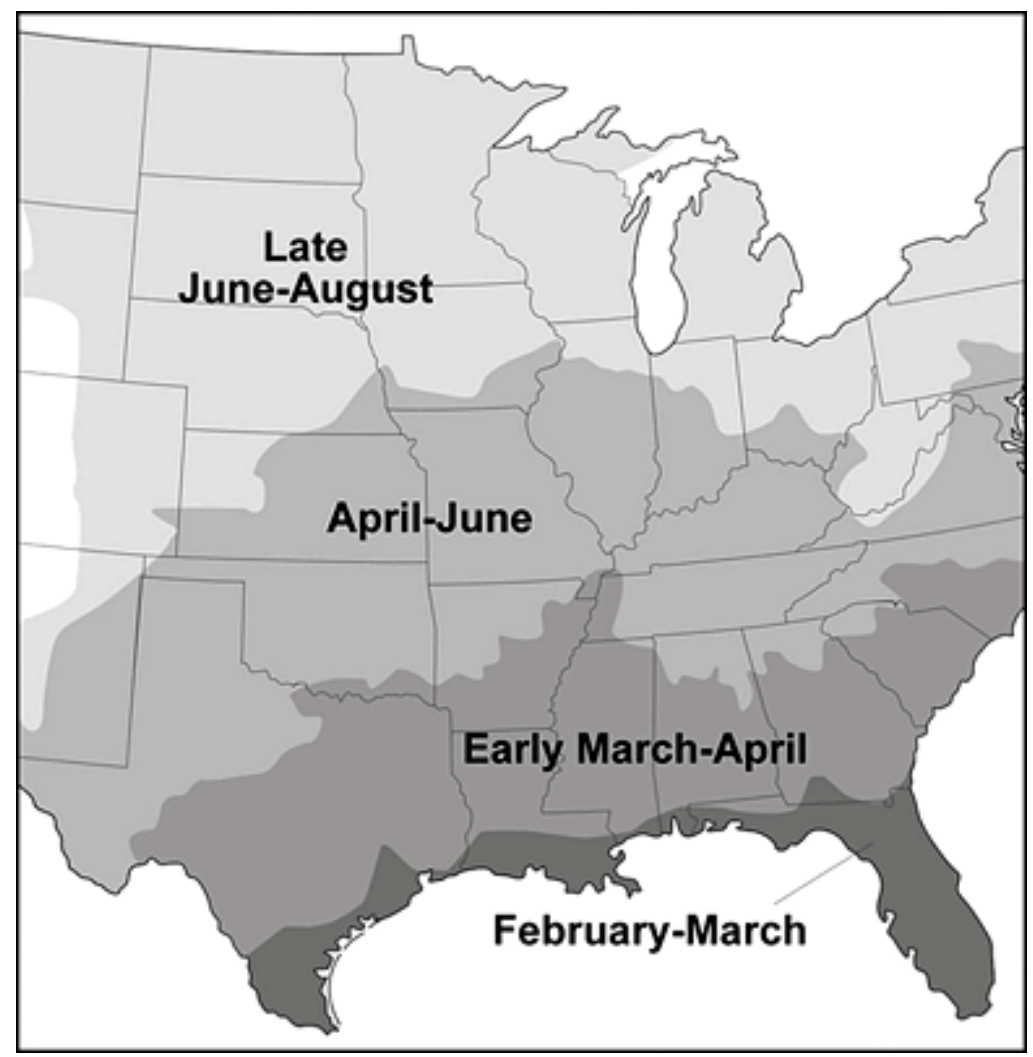

Fig. 2. Dates for first expected appearance of CEW in the central United States. Data is from Isard et al. (5), map reproduced by NIU Cartography Laboratory. 
CEW migration is highly dependent on weather and wind patterns. Research findings for CEW migration in the northeastern United States have indicated that CEW can be carried between two points by surface and upper air wind currents, notably from a south-to-north direction (9). Potato leafhopper (Empoasco fabae) influxes from source regions in Louisiana into Illinois were examined by (4) and found that their migrations are associated with southerly low-level winds and these insects would fall into fields during stormy or rainy weather associated with frontal boundaries. Research by Welshans et al. (9) observed that green cloverworm (Plathypena scabra) migrated northward to central Iowa during periods of prolonged southerly winds in Iowa and vicinity from southern United States source regions. More recently, Hoy et al. (3) determined that aster leafhoppers (Macrosteles quadrilineatus) migrated into Ohio fields from three source regions, presumably near the Gulf of Mexico, northern Great Plains, and nearby midwestern states. Additionally, spores of Asian soybean rust (Phakopsora pachyrhizi) have been observed to migrate in a similar fashion (5). The goal of this research is to take previous findings on CEW migration and apply them specifically to the Midwest, an area at a higher risk from more substantial yield losses than the northeastern United States. In addition, the atmospheric processes assisting possible CEW migrations will be analyzed more in-depth to assist producers in recognizing key weather patterns days in advance of a potential CEW infestation to minimize costs associated with treatment and yield losses.

\section{CEW Blacklight Trap Count and Weather Map Data}

In order to identify CEW migration dates in the Midwest, CEW trap count data were gathered from a Del Monte Inc., blacklight trap located near Rochelle, IL (35 km south of Rockford, IL) from 1958-2003. No data were available in 1992, 1997-2000, and 2002, thus leaving 40 years of blacklight trap count data for Rochelle. The data were organized annually by J ulian days; therefore, to later facilitate compatibility with weather data that was only available in a Gregorian calendar format, a conversion from J ulian days to its equivalent day on a Gregorian calendar was necessary.

Arbitrarily defined "high CEW events" were defined as consisting of a minimum of $50 \mathrm{CEW}$ caught over a five-day period or 100 in ten days. To further reduce the number of events to a manageable but yet significant number, "major CEW events" (defined as at least three consecutive days with a total blacklight trap count of 100 or more) were identified through the period and used for analysis in this research.

In order to link weather patterns to CEW migration during major CEW events, daily historical surface weather maps were obtained from the National Oceanic and Atmospheric Administration's (NOAA) Central Library US Daily Weather Maps Project website (http:/ / docs.lib.noaa.gov/ rescue/ dwm/ data_rescue daily_weather_maps.html). Weather patterns were then analyzed from the beginning to the end of each major CEW event to determine if similar weather patterns existed.

\section{Relationship Between Weather/ Wind Patterns and High CEW Blacklight Trap Counts}

After analysis of the blacklight trap count data for Rochelle was completed, 12 major CEW events were identified in the 40 years of available data between 1958 and 2003 (Table 1). All of the events at Rochelle occurred between August 21 and October 8. Interestingly, all events were observed prior to 1985, indicating a decrease in major CEW infestations in northern Illinois in the last two decades.

In order for CEW to migrate northward in association with weather patterns, they must be able to lift out of the canopy layer. Convective cells, or thermals, are created by the differential heating of opposing land surface types, and allow warm air parcels to rise into the lower atmosphere. CEW can be absorbed into these thermals, allowing them to lift out of the canopy and transport through wind currents, both at the surface and in the lower levels of the atmosphere. 
Symposium: Increasing Concerns about H. zea Susceptibility to Pyrethroids in the Midwestern USA

Table 1. Dates of major CEW events at Rochelle, IL (1958-2003).

\begin{tabular}{|l|l|}
\hline Event number & Event dates \\
\hline $\mathbf{1}$ & August 21-26, 1959 \\
\hline $\mathbf{2}$ & August 26-31, 1962 \\
\hline $\mathbf{3}$ & October 5-8, 1964 \\
\hline $\mathbf{4}$ & September 18-21, 1965 \\
\hline $\mathbf{5}$ & September 20-22, 1968 \\
\hline $\mathbf{6}$ & September 6-8, 1970 \\
\hline $\mathbf{7}$ & September 20-24, 1970 \\
\hline $\mathbf{8}$ & September $8-10,1971$ \\
\hline $\mathbf{9}$ & August 29-September 4, 1973 \\
\hline $\mathbf{1 0}$ & September 25-30, 1973 \\
\hline $\mathbf{1 1}$ & September 23-27, 1981 \\
\hline $\mathbf{1 2}$ & September 20-24, 1984 \\
\hline
\end{tabular}

A review of the surface weather maps on the day of the highest CEW blacklight trap count indicated a remarkable similarity in the weather pattern present on the surface maps. Typically, a surface high-pressure cell was located in the eastern United States, with winds moving clockwise around the high. A surface low-pressure cell was frequently observed to be in the High Plains or Upper Midwest, to the west of Rochelle. Counterclockwise wind flow around a low-pressure system indicates winds blowing from south-to-north to the east of the low-pressure cell and west of the high-pressure cell (including areas near Rochelle and points south). Additionally, low-pressure systems are usually associated with frontal boundaries that divide warm and cold air, and/ or moist and dry air. Precipitation is frequently observed along or near frontal boundaries, and indicates an area where both upward and downward motion exists. A frontal boundary, sometimes associated with precipitation, was always observed over or to the north of Rochelle during each major event.

Given a strong relationship among major CEW event dates and observed surface weather patterns, a model of CEW movement related to the weather was created (Fig. 3). Southerly flow between a high located to the east and a low to the west allows adult CEW from a source region in the southern United States to be transported in the "Insect Migration Pump," indicated by the yellow arrow pointing northward between the high and low-pressure cells. The CEW will continue to move in the same direction as the wind flow until an area of downward motion is encountered, either at a frontal boundary and/ or area of precipitation. At this point, the CEW will be forced to drop out of the sky, an area referred to as the "Drop Zone" (Fig. 4). Sweet corn fields located near or in the Drop Zone are at highest risk from being affected by significant numbers of CEW. Preparations should be taken if weather forecasts indicate such a pattern is going to occur and CEW are known to be active and could potentially migrate into your area during favorable times of the year for CEW movement. 
Symposium: Increasing Concerns about H. zea Susceptibility to Pyrethroids in the Midwestern USA

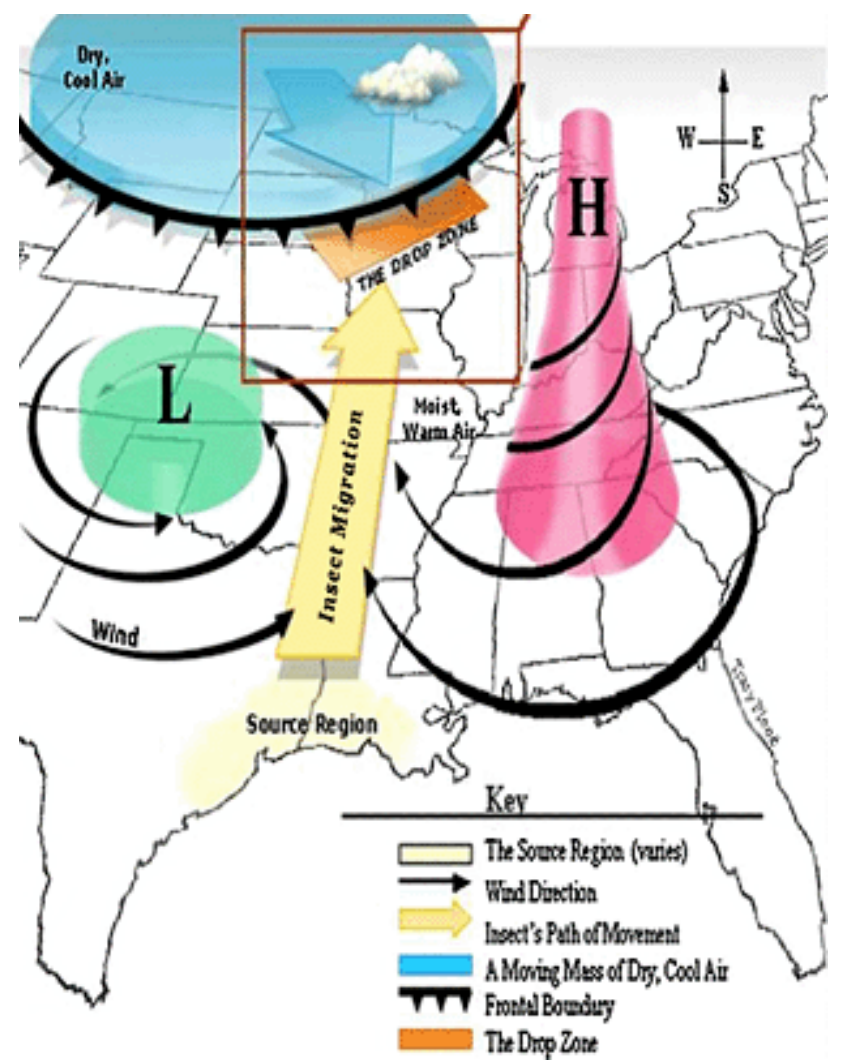

Fig. 3. Typical weather pattern setup favorable for CEW/insect migration (2).

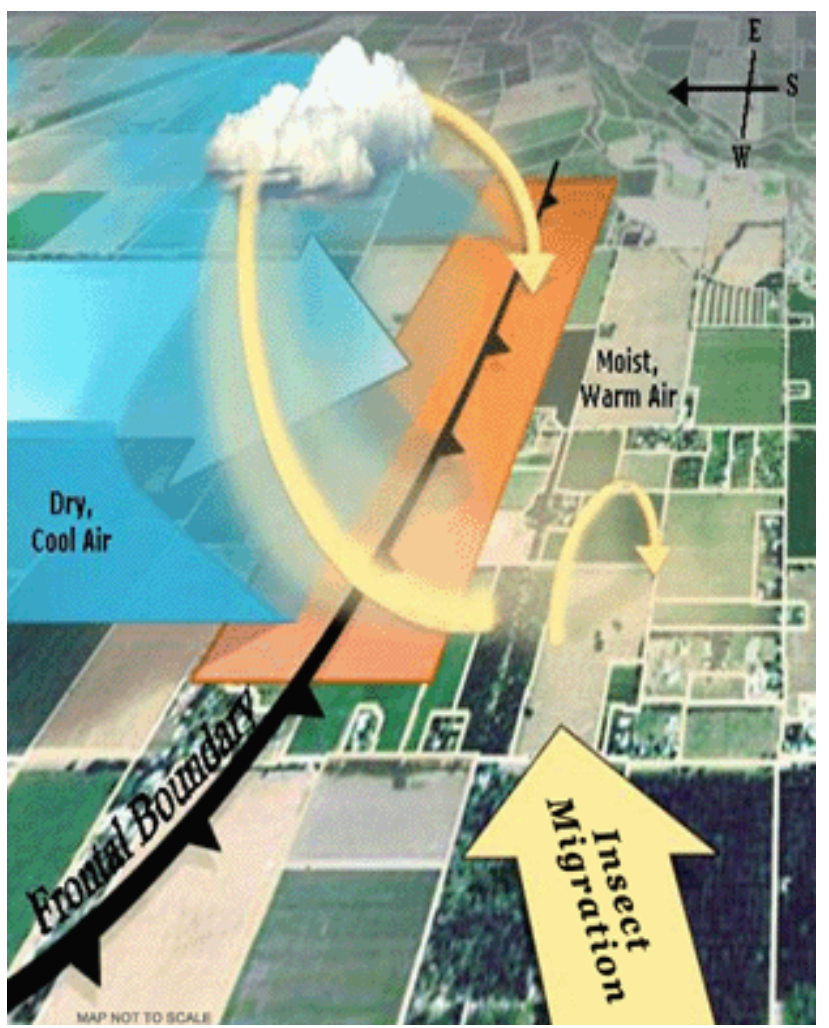

Fig. 4. "Drop Zone" (area of greatest risk of observing the highest CEW trap counts) (2). 
Case Event at Rochelle: September 24, 1984

On September 24, 1984, the highest total daily CEW blacklight trap count $(1,075)$ occurred at Rochelle (Fig. 5). The weather pattern several days before and including the day of the event was very favorable for movement of CEW northward into northern Illinois. Given the high blacklight trap count, a source region of adult CEW must have been present to the south of Rochelle. On September 21, 1984, the surface weather map at 6AM Central time (Fig. 6) indicated a surface high-pressure cell centered over North and South Carolina and surface low-pressure cells positioned over southeast Montana and Arizona, with a frontal boundary stretching from the low in Montana eastward to Iowa, Illinois, and Indiana. The weather pattern indicated an eastward progression of the surface low-pressure systems on September 22 (Fig. 7) and September 23 (Fig. 8), with the surface high pressure remaining largely stationary over the eastern United States, resulting in southerly surface wind flow for a prolonged period of time. By the morning of September 24 (Fig. 9), the surface low pressure had moved into western Iowa, with a frontal boundary draped across southern Minnesota, Wisconsin, and the lower peninsula of Michigan. Southerly flow at the surface was still observed in northern Illinois, but an abrupt change in wind direction (from southerly to easterly or northeasterly) north of the frontal boundary in southern Wisconsin was observed. Therefore, given downward movement due to the presence of cooler air and attendant precipitation in the vicinity of the frontal boundary, the CEW were forced to drop out of the sky over northern Illinois and southern Wisconsin in the vicinity of the frontal boundary, resulting in high blacklight trap counts at Rochelle not only on September 24 but for several days earlier given the slow movement of the surface low-pressure system and frontal boundaries.

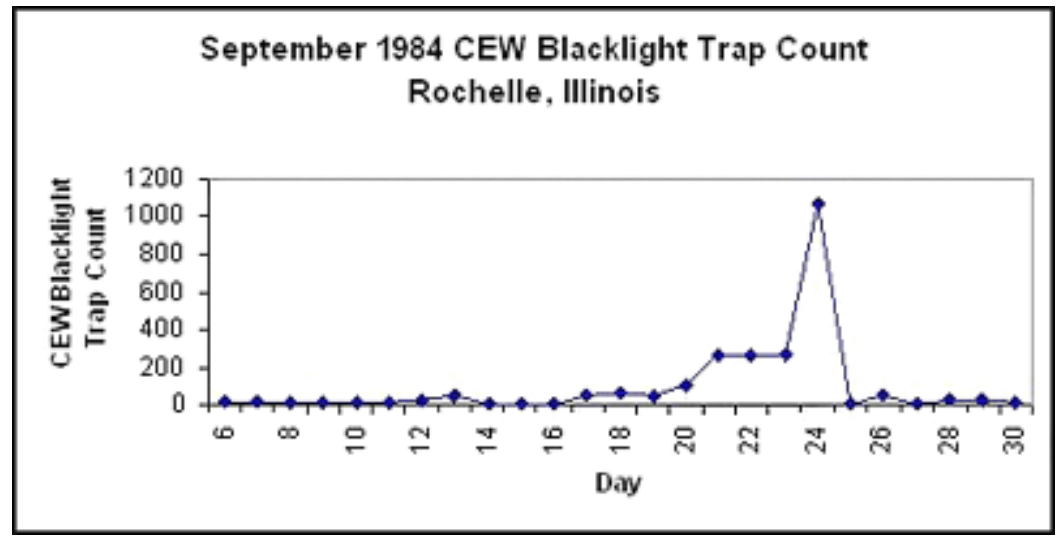

Fig. 5. Total CEW blacklight trap counts for Rochelle, IL, September 1984 (data provided by Del Monte Foods Inc.). 


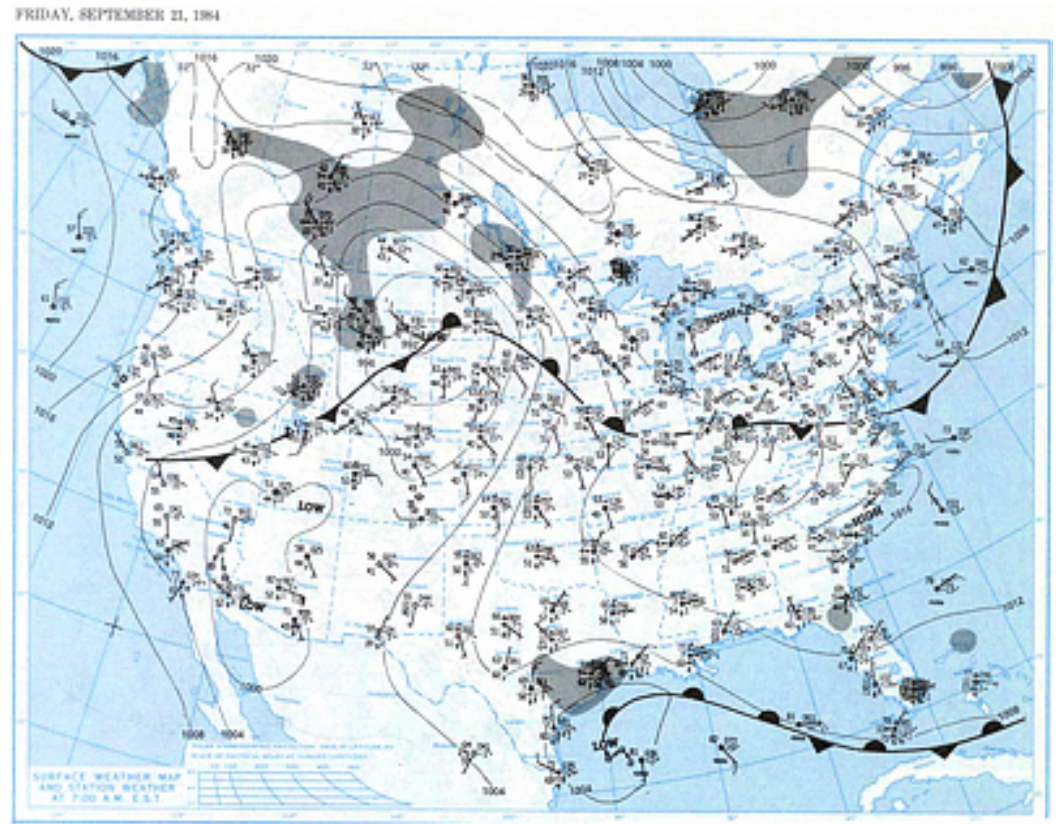

Fig. 6. Surface weather map for 6AM Central Time, September 21, 1984 (NOAA).

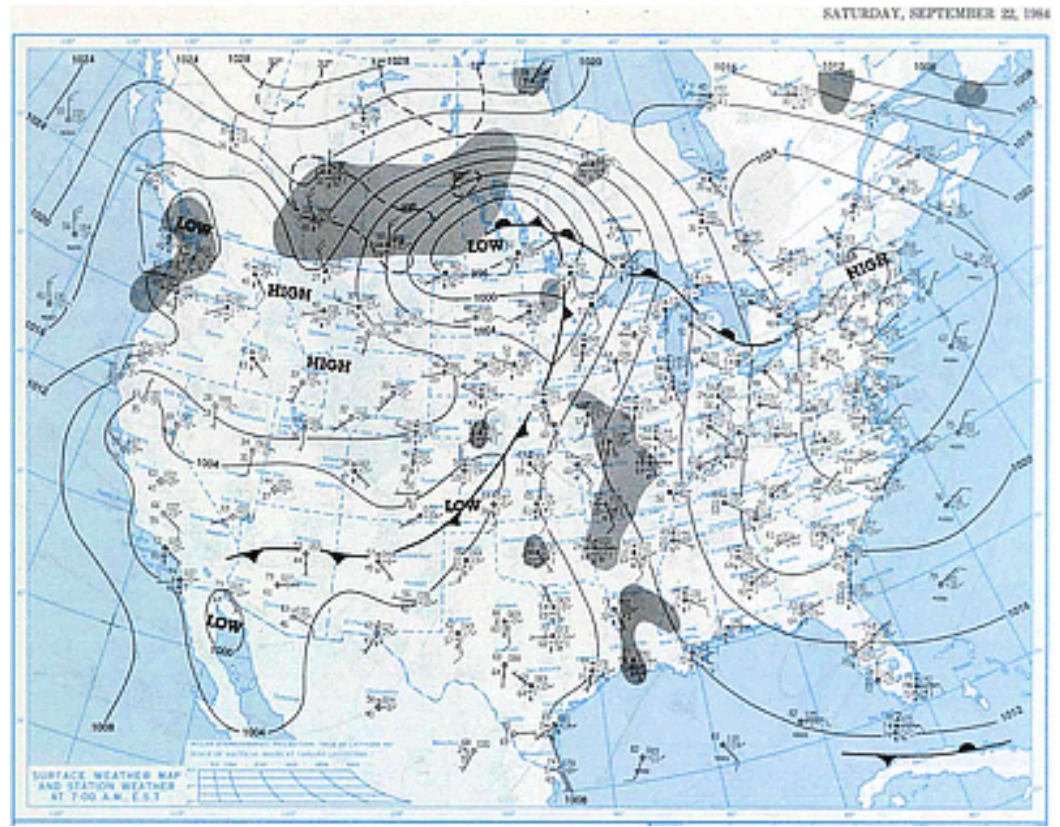

Fig. 7. Surface weather map for 6AM Central Time, September 22, 1984 (NOAA). 


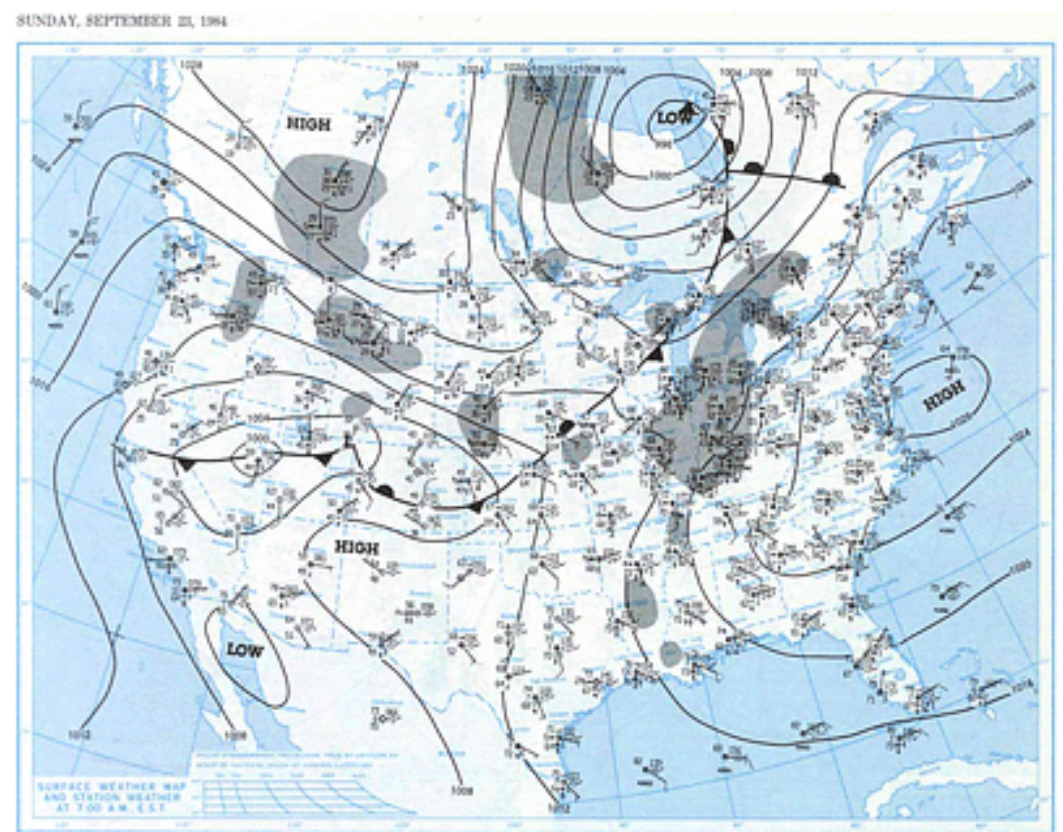

Fig. 8. Surface weather map for 6AM Central Time, September 23, 1984 (NOAA).

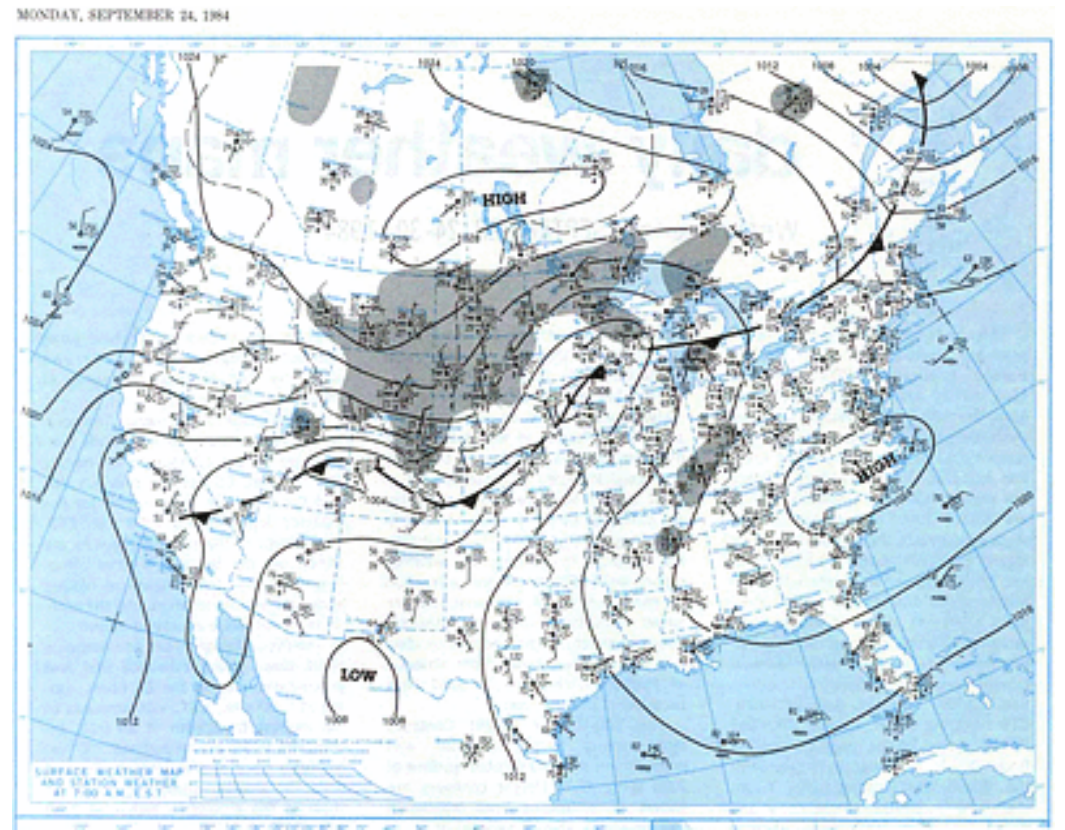

Fig. 9. Surface weather map for 6AM Central Time, September 24, 1984 (NOAA).

\section{Forecasting CEW events}

During the summer, the weather pattern previously described and presented in the case event at Rochelle in 1984 that allows CEW to move north into the Midwest is fairly common and often persistent. Because weather patterns are often slow to change in the summer, they can generally be predicted days in advance. Based on weather conditions and knowledge of the CEW source region, a pest management risk forecasting scheme can be developed and regions of potential CEW infestations can be identified. At the request of entomologists and commercial users in the Midwest, a daily forecasting product highlighting geographic areas in the Midwest at risk of CEW migration and drop-out was developed in 2006 (7). The Insect Migration Risk Forecast (IMRF) predicts favorable weather patterns that could produce CEW migration events anywhere 
from 1 to 5 days in advance. Regional/ local producers, therefore, have lead time to treat the sweet corn in correlation with their familiarity of CEW activity and expected arrival in their area, thus mitigating crop losses.

\section{Conclusion}

CEW are not able to overwinter in many areas north of Interstate 80, therefore, they must be transported northward to affect the majority of sweet corn fields in the Midwest. Surface weather maps indicate that during major CEW events (three or more consecutive days of blacklight trap counts of 100 or more/ day) at Rochelle, Illinois, a high-pressure cell was located to the east, a low-pressure cell was located to the west, and a frontal boundary associated with the low-pressure cell was observed near or to the north of Rochelle. Given a source region of adult CEW to the south, the CEW could migrate northwards through an "Insect Migration Pump" containing south-to-north wind flow between the high and low-pressure systems and had a tendency to drop out of the sky when a frontal boundary and/ or area of precipitation was encountered, an area referred to as the "Drop Zone." Although some uncertainty is always present in weather forecasting, such weather patterns can be forecasted with fairly high confidence. The producer or pest manager can use the forecast as a decision support tool and take on a more "proactive" stance to CEW migration, potentially reducing treatment costs and yield losses due to advanced preparation for expected CEW infestations.

\section{Acknowledgments}

Thanks to W. Hutchison and the anonymous reviewers for suggestions on how to improve this manuscript.

Literature Cited

1. Capinera, J. L. 2000. Corn earworm. Online. Featured Creatures, Pub. No. EENY145, Dept. of Entomol. and Nematol., Univ. of Florida, Gainesville.

2. Foster, R., and Flood, B. R. 2005. Vegetable Insect Management. Meister Pro Publisher, Willoughby, $\mathrm{OH}$.

3. Hoy, C. W., Heady, S. E., and Koch, T. A. 1992. Species composition, phenology, and possible origins of leafhoppers (cicadellidae) in Ohio vegetable crops. J. Econ. Entomol. 85:2336-2343.

4. Huff, F. A. 1963. Relation between leafhopper influxes and synoptic weather conditions. J. Appl. Meteorol. 2:39-43.

5. Isard, S. A., Main, C., Keever, T., Magarey, R., Redlin, S., Russo, J . M., Gage, S. H., Miles, M. R., and Hartman, G. L. 2004. Weather-based assessment of soybean rust threat to North America: Final report to APHIS. Online. Plant Pest Info., Soybean Rust. USDA-APHIS, Washington, DC.

6. NASS. 2002. 2002 census of agriculture, Table 35: vegetables and melons harvested for sale: 2002 and 1997. Sweet corn. Online. Nat'l. Agric. Stat. Serv. (NASS), USDA, Washington, DC.

7. Sandstrom, M., and Changnon, D. 2006. Insect Migration Risk Forecasts. Online. Author's website, in cooperation with Northern Illinois Univ., DeKalb, IL.

8. Snow, J. W., and Copeland, W. W. 1971. Distribution and abundance of the corn earworm in the United States. U.S. Dept. Agric. Plant Pest Control Div. Coop. Econ. Insect Rep. 21:71-76.

9. Welshans, M., Fleischer, S., Knight, P., and Miller, D. 2004. An exploratory study of corn earworm immigration into the northeast US via air currents. Poster Session 5, Spatial Climate Technologies and Products. 14th Conf. on Appl. Climatol., 84th Ann. Meet. of the Amer. Meteorol. Soc., Seattle, WA.

10. Wolf, R. A., Pedigo, L. P., Shaw, R. H., and Newsom, L. D. 1987. Migration/ transport of the green cloverworm, Plathypena scabra (F.) (Lepidoptera: Noctuidae), into Iowa as determined by synoptic-scale weather patterns. Environ. Entomol. 16:1169-1174. 